\title{
NOTES
}

\section{"A YOUNG WOMAN MEETS WALT WHITMAN": ANNE MONTGOMERIE TRAUBEL'S FIRST IMPRESSION OF THE POET}

Among the Whitman papers in the Library of Congress that came from the late Gertrude Traubel's Germantown, Philadelphia home in the 1980s is a short typewritten essay entitled "A YOUNG WOMAN MEETS WALT WHITMAN, As told by Anne Montgomerie to her daughter, Gertrude Traubel." Anne Montgomerie Traubel (1864-1954) became the wife of Horace Traubel, the poet's Boswell, in a ceremony in the poet's Mickle Street house. The marriage took place on May 28, 1891, when nineteen people crowded into the second-story bedroom of Whitman's row house in a working-class neighborhood. Traubel shifted the occasion from his father's house to Whitman's when the poet, within ten months of his death, could not leave his home. "He could not come up to my father's house," Traubel recorded in the yet-to-bepublished final pages of With Walt Whitman in Camden in the Library of Congress. "Could we all come to him? He seemed greatly pleased, 'Do you wish it? Do you really wish it?' Yes indeed. 'Well then, come-yet come, Horace, boy, all of you.' "'

Whitman may have been ill, but the excitement brought out his love for the youthfulness of life. "I threw open the door," Traubel recorded on the night of his marriage, and "they came upstairs. W. exclaimed, "Welcome, welcome, welcome all,' and they came in-a whole troop-with strangers (several of them whom I am sure Mrs. Davis [the poet's housekeeper] had summoned). . . . And they clustered about the bed and through the room, W. showing some anxiety to get them seats. W. very loving with all-particularly to the girls-addressing Anne as 'Anne darling' and Agnes [T. Lychenheim] as 'darling'-kissing both fervently and sitting Anne at his side on the bed." Traubel apparently had said nothing of wedding plans to Whitman until that day, appearing to think his expected marriage to the attractive young woman far inferior in importance to his doings with Whitman. Appropriately perhaps, they were married in a ceremony that consisted mainly of a reading of poems by Whitman and Emerson. Whitman, Traubel recorded, appeared struck with the ceremony, exclaiming afterward ("as if out of inner abstraction"), "The marriage bond and police law forever!" To this mysterious outburst, he added: "At least for the present-at least for one day."

For Anne Montgomerie, the participation of Whitman in her marriage may well have meant her own marriage to the poet's memory, which her husband so faithfully kept before the public eye until his death in 1919. As she recorded in the document prepared by her daughter, she first met Whitman in the spring of either 1885 or 1886 . She thought the poet as lovely as her father, and it is noteworthy that Anne had not read any of Whitman's poetry when she was first so charmed by his magnetic personality. 


\section{A YOUNG WOMAN MEETS WALT WHITMAN}

As told by Anne Montgomerie to her daughter Gertrude Traubel

The first time I met Walt Whitman (in the spring of 1885 or 1886) I was not attracted to him. At that time I had [not] read any of his work. I went over to Camden with Horace and a number of other people. We were expected, and Walt received us in his room upstairs. He sat in a large chair by the window. We sat or stood about: each in turn being personally presented to him by Horace.

As I stood beside his chair, I felt a strange power radiating from him with so much force that I felt pushed away. This was a thing outside my experience. I was dismayed, and did not utter a word. Just kept still and wondered, "What is that?"

I was impressed by the tranquillity with which he received our greetings and chat, and the ease with which he offered his hospitality. But I felt that I had to know more about that power.

So, very soon, I went to see him again. This time I went alone. The power was still there. He gave me a sort of cheery greeting and asked me to sit down. He didn't say much. Whatever he was doing when I entered the room, he kept on doing. He was murmuring or humming to himself. Soon that sense of being a stranger went away and never returned.

He did not feel remote from anything: people or trees or flowers or animals. He made me feel that all things are in space together. I did not have to convince myself that I was at home with him and welcome, any more than I had to convince myself that I was at home and welcome with my father. I felt that I belonged here and that this man was as lovely as my father.

The room was the second-story front bedroom of 328 Mickle Street in Camden. It was large and wide, with a low ceiling. There were three windows across the north end and overlooking the street. He sat at the east one, which was the one farthest from the door. He sat in a very large and heavy maple chair, similar to porch rockers. It had very wide arms, which made it convenient for handling his letters and papers. The window-ledge, originally very narrow, Walt had had enlarged by a piece of board. There he kept his ink, pens and pencils, scissors, mucilage, a glass of water, and some small thing to keep a flower in. They were necessary to him. He liked to have a sprig of mint there, or lemon verbena, or a leaf of rose-geranium. I have seen him lift the glass containing a flower, smell it, touch it lightly, smile at it and put it back in the window-ledge.

Whitman's physical frame was very large. He was over six feet in height, and broad and powerful. In good health and in semi-health, his weight was about 200 pounds. His clothes fitted loosely. His coats never had [any] stuffing to give them shape, yet they fit and had a real style of their own. I admired his shirts. They were made of thin, fine, white material, enormously wide and loose, open at the neck for several inches, and with a broad collar which was particularly effective when worn without a coat. When he was dressed to go downstairs, or for the street, he wore grey home-spun, and looked exceedingly handsome with his silvery hair and beard streaming over his head and shoulders.

I had been told that Whitman was different from other people. I did not feel that he was different but that he was better. I felt a quality of significance about him which I did not gauge then and don't yet. 